\title{
Types and modeling of intercalation in alluvial fan reservoir-A case study of Guantao Formation in the Du 84 Block, Shu-1 area, Western Sag of Liaohe Depression
}

\author{
Yuanchao Zheng ${ }^{1, a}$, Tailiang Fan ${ }^{1, b}$ and Zhiqian $\mathrm{Gao}^{1, \mathrm{c}}$ \\ ${ }^{1}$ School of Energy Resources, China University of Geosciences, Beijing100083, China; \\ azyc_cugb@126.com, ${ }^{\text {b}}$ fantl@cugb.edu.cn, ${ }^{\mathrm{c}}$ gzq@cugb.edu.cn
}

Keywords:Liaohe oilfield, Guantao Formation, heavy oil, alluvial fan, intercalation

\begin{abstract}
The Western Depression of the Liaohe Basin is the major exploration area of the Liaohe Oilfield, and the production formation of Guantao in Du84 block of the Shu-1 area contains extra heavy oil with a depth of 530-640m.Steam Assisted Gravity Drainage(SAGD) method had been applied to the development of heavy oil.The distribution of intercalations has great influence on the expansion of steam chamber during SAGD development, based on the cores, two types of intercalations(muddy intercalation and physical property intercalation) were identified, and in combination of well log suits, intercalation's log response templates were built.In order to ensure optimal hydrocarbon recovery and sustain production, cores, log curves and other relevant data were collected for building fine reservoir model, with the constraints of sedimentary microfacies, dense well log interpretation results, the model are suitable for characterizing the heterogeneity of the reservoir.
\end{abstract}

\section{Introduction}

Alluvial fans are sedimentary deposits formed at the base of mountain fronts as rivers emerge out of the mountain range[1].Blair andMcPherson(1994)[2] classified alluvial fan styles based on processes combinations, they divided alluvial fans into fluvially formed fans and debris-flow fans.Due to the relatively short sediment-transport distance, fan deposits typically are coarse-grained and poorly sorted. At present, researches on alluvial fan mainly focuses on geomorphological features[3] and the processes operating on the fans,morphology is mainly controlled by allogenic(such as catchment characteristic,tectonics,climate,and base-level change)and autogenic(internally derived thresholds within the fan system)factors. Compared with other terrestrial sediments, sedimentary architecture and stacking pattern of alluvial fans are very complex.Outcrops and cores are the main data sources for the research of sedimentary architecture, and the research of physical modeling can reveal the dynamic process of alluvial fan.

Steam Assisted Gravity Drainage(SAGD) Process has been applied successfully for the production of bitumen and heavy oil in many oilfields in the world, and this method is also applied to exploit shallow heavy oil reservoirs in Liaohe Oilfield. Stacking patterns of sands and distribution of intercalation have significant influence on the effect of reservoir performance and recovery.Intercalations in the reservoir are the main factor affecting the expansion of hot steam chamber and the flow of oil during SAGD,therefore,better understanding of the intercalation distribution is of great importance for enhancing recovery.In this paper, on the basis of large amount of data from cores, dense wells, we aims at better delineating of intercalation distribution, which will provide basis for development design.

\section{Geological Setting}

Du 84 Block of Liaohe Oilfield is located in the middle section of the Huanshu upper plateau on the west slope of the Liaohe faulted and depressed basin[4]. Du 84 Block is bounded by du-32 fault in the north, du-79 fault in the east, and du-115 fault in the west.The Guantao Formation of the upper Tertiary in Cenozoic containing extra heavy oil, and the structure is a monocline to the 
Southeastwith the dip at about $2-3^{\circ}$. The study area is about $5.24 \mathrm{~km}^{2}, 3 \mathrm{D}$ seismic data covers most of the Du84 Block, and over1700 production wells have been drilled in this area.

The Guantao Formation, was deposited in a wet alluvial fan environment,150-210m thick, is divided into 5 groups $\left(\mathrm{Ng}_{1}, \mathrm{Ng}_{2}, \mathrm{Ng}_{3}, \mathrm{Ng}_{4}, \mathrm{Ng}_{5}\right)$ and then into 10 sublayers $\left(\mathrm{Ng}_{1}{ }^{1}, \mathrm{Ng}_{1}{ }^{2}, \mathrm{Ng}_{2}{ }^{1}, \mathrm{Ng}_{2}{ }^{2}\right.$, $\mathrm{Ng}_{3}{ }^{1}, \mathrm{Ng}_{3}{ }^{2}, \mathrm{Ng}_{4}{ }^{1}, \mathrm{Ng}_{4}{ }^{2}, \mathrm{Ng}_{5}{ }^{1}, \mathrm{Ng}_{5}{ }^{2}$ ).

\section{Facieology}

There are more than 1700 development wells in the study area, and logging series are complete. The stratigraphic approach to analyze the sedimentary framework employs sedimentary facies and facies associations. Cores are first-hand material which are widely used in description of sedimentary information underground. Information like color, lithologic composition,sedimentary structures, fossils, palaeostream patterns are helpful to the recognition on sedimentary microfacies.In Guantao Formation, lithologiesare mainly anisometric conglomerate, sandy conglomerate, anisometric sandstone and mudstone.

\section{Intercalations}

In cores, intercalations have been classified into two types according to the genesis and seepage characteristics(Table1,Figure1,Figure2).Muddy intercalation is mainly composed of mudstone and siltymudstone,usually formed during the hydrodynamic condition change from strong to weak,the responding characteristics of log curvesare:(1)high values inacoustic transit timeand gamma ray;(2)obvious rise in CON value, obvious decline in resistivity value;(3)porosityand permeability in a low value.Physical property intercalationsis mainly composed of fine sand and siltysand, usually formed by lithology change or diagenesis, the porosity and permeability are relatively low and it can be barrier to fluid flow,the responding characteristics of log curvesare:(1)acoustic transit time is relatively low,CON value ishigh;(2)obvious decline in resistivity;(3)porosity and permeability in a low value.

Table 1Intercalation identification template of Guantao Formation, Du 84 Block

\begin{tabular}{|c|c|c|c|c|}
\hline \multirow[t]{2}{*}{ Intercalation type } & \multicolumn{2}{|c|}{ Electric characteristics } & \multicolumn{2}{|c|}{$\begin{array}{c}\text { Physical property } \\
\text { characteristics }\end{array}$} \\
\hline & $\begin{array}{c}\text { Well log } \\
\text { characteristics }\end{array}$ & Log value range & $\begin{array}{c}\text { Porosity/ } \\
\%\end{array}$ & $\begin{array}{c}\text { Permeability/ } \\
10^{-3}{ }^{2} \mathrm{~m}^{2}\end{array}$ \\
\hline $\begin{array}{l}\text { Muddy } \\
\text { intercalation }\end{array}$ & $\begin{array}{c}\text { Obvious rise in } \\
\text { gamma ray, acoustic } \\
\text { transit time. Decline } \\
\text { in resistivity }\end{array}$ & $\begin{array}{l}\text { AC/(us/m):350-600 } \\
\left.\text { CON(mS.m }{ }^{-1}\right): 30-150 \\
\mathrm{R}_{\mathrm{LLD}}(\Omega \mathrm{m}): 10-60 \\
\mathrm{R}_{\mathrm{LLS}}(\Omega \mathrm{m}): 5-50\end{array}$ & $0-3$ & $0-1$ \\
\hline $\begin{array}{l}\text { Physical property } \\
\text { intercalation }\end{array}$ & $\begin{array}{l}\text { Low value in } \\
\text { acoustic transit time, } \\
\text { obvious decline in } \\
\text { resistivity }\end{array}$ & $\begin{array}{l}\text { AC/(us/m):260-450 } \\
\left.\text { CON(mS.m }{ }^{-1}\right): 3-20 \\
\mathrm{R}_{\mathrm{LLD}}(\Omega \mathrm{m}): 50-320 \\
\mathrm{R}_{\mathrm{LLS}}(\Omega \mathrm{m}): 40-300\end{array}$ & $0-20$ & $5-300$ \\
\hline
\end{tabular}

\section{Reservoir modeling}

\subsection{Methodology and workflow.}

The reservoir characterization process starts with collecting all relevant data, quality control(QC), and analyses. In order to meet the requirement of reservoir development, fine grid was built, results of geological studies, geophysical, petrophysical data were collected then integrated into the fine gird, data analysis was run, geostatistical method was applied, and reservoir characterization can be achieved. 


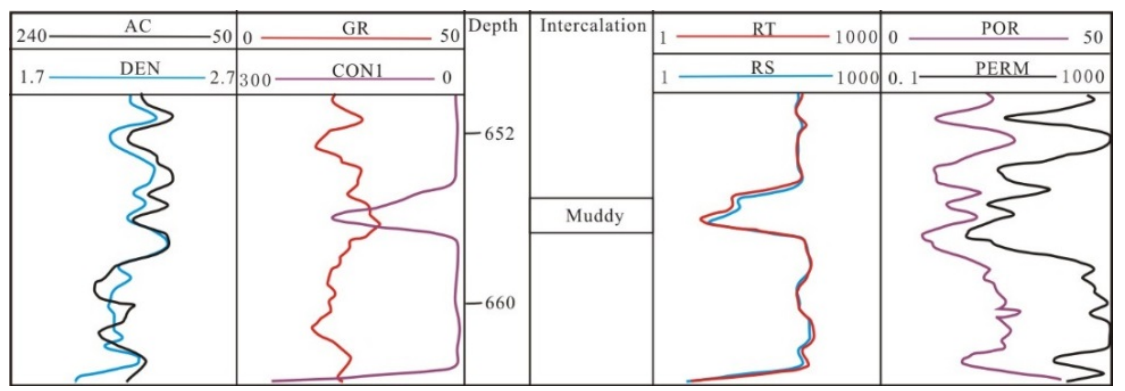

Fig. 1 Log characteristics of muddy intercalation

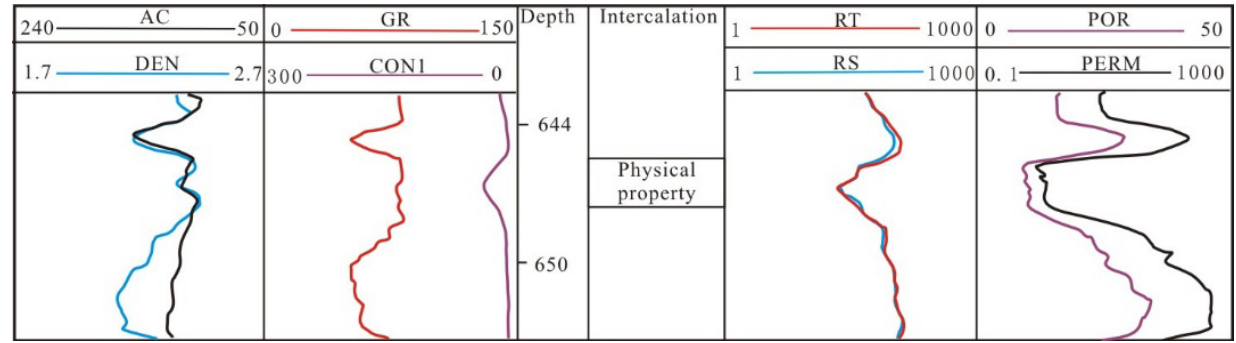

Fig. 2 Log characteristics of physical property intercalation

\subsection{Data collection.}

The data list is presented in Table 2. To comprehend the complex distribution of intercalations, all available data were collected and compiled to modeling database.

Table 2Du 84 Block heavy oil reservoir modeling data list

\begin{tabular}{ll}
\hline Category & Data Item \\
\hline Well head & Location(x,y), Kelly bushing, total depth \\
Well path & Well deviation data \\
& Conventional log and interpretations (gamma, resistivity, porosity, permeability, \\
& Sw, density, caliper etc.) \\
Well logs & Lithofacies (reservoir quality indicator) \\
& Intercalation interpretation results \\
Core data & Lab test of petrophysical data \\
Completion & Wellbore data, Perforation, length \\
Well tops & Marker well name, depth \\
Sedimentary & Sedimentary microfacies and its boundary \\
Seismic & Original volume and 4D seismic data \\
Surveillance & Well temperature surveillance data \\
Reports & Any previous studies and reports \\
\hline
\end{tabular}

\subsection{Grid design and framework building.}

Intercalations are the main geological factor affect the expansion of steam chamber during SAGD. In order to quantitatively investigate the heterogeneity of the reservoir, the geomodel wasconstructed on a grid containing $10 \mathrm{~m} * 10 \mathrm{~m} * 0.125 \mathrm{~m}$ cell with a total of about $38,658,100$ cells, the geometry of this grid wasgoverned by the geometry of the bounding surfaces.Detailed well-to-well correlation was run, and well tops were acquired and integrated into the database, 11 key stratigraphic surfaces were built with a convergence algorithm.In order to construct a robust geological model, layering must be consistent with the defined stratigraphic framework, and with the vertical resolution of $0.125 \mathrm{~m}$, characterization of intercalations can be achieved.

\subsection{Facies Modeling.}

Through core analysis and log interpretation, sedimentary microfacies were identified, lithofacies and petrophysical properties can be obtained at well locations.Sedimentary microfacies model was built by deterministic method with digitized microfacies boundary polygons, each microfacies was assigned to specificdiscrete code, and microfacies modeling was processed layer by layer.

Lithofacies logs were acquired by using the cored wells and their log responses as template for identification, lithofacies including intercalations were upscaled into the fine grid, the percentagesof 
lithofacies derived from logs were analysed and used as soft constraints of modeling process,after variogram analysis, each microfacies was appliedtheSequential Indicator Simulation(SIS)method to model lithofacies distribution.

\subsection{Petrophysical property modeling.}

The most important petrophysical property includes porosity, permeability and water saturation. These parameters will be used in reservoir simulation to predict reservoir performance during SAGD development.In this reservoir, lithofacies have great influence on porosity distribution, when building porosity model, we concerned about lithofacies distribution, variograms were caculated for each lithofacies, and Sequential Gaussian Simulation(SGS)were applied to building porosity model.Then the porosity model was used as soft constrains for building permeability model with SGS method. For water saturation model, the oil-water contact for each sublayer were identified, and the boundary polygons were integrated into the database. Outside the contact, $\mathrm{S}_{\mathrm{w}}$ were set to $100 \%$, and within the boundary,with the interpreted $S_{w} l o g$, kriging interpolation were used for building $\mathrm{S}_{\mathrm{w}}$ model.The section(Figure 3) showsthe fluid distribution of the model, it can characterizing the reservoirheterogeneity.

\section{Summary}

Muddy intercalation and physical property intercalation are main types of intercalation in Du-84 block, Guantao formation. They are main barrier for fluid flow, during SAGD development, well temperature surveillance data demonstrated the influence on steam chamber expansion. Multiple data integrated, fine grid reservoir modeling can characterizing the heterogeneity of the intercalation distribution and physical property. Deterministic and stochastic modeling methods are both used in this case, due to high dense wells, the original lithofacies and physical property interpretation results had great influence on the final reservoir model. The model is too big for whole reservoir simulation without upscaling, but for specific well group, it is applicable to well simulation to evaluate the influence of distribution of intercalation on reservoir performance.

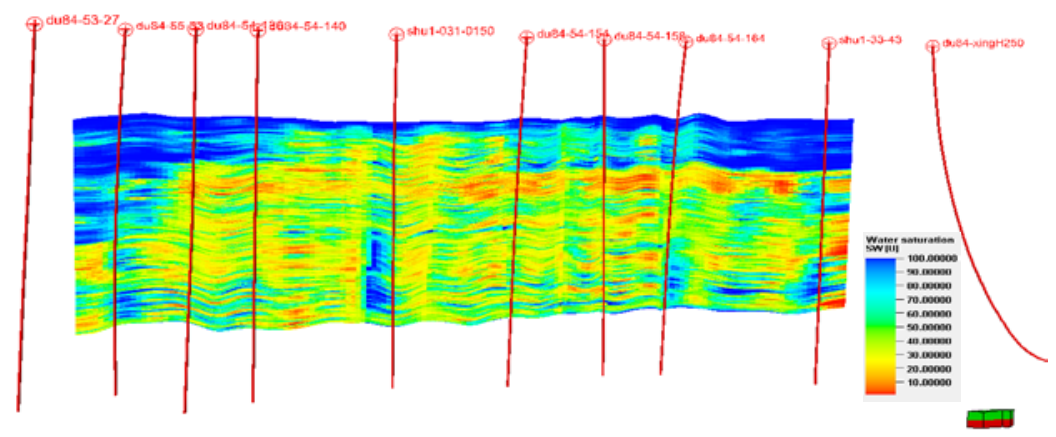

Fig. 3 Water saturation section of 3D geological model.

\section{References}

[1].Bull, W. B. The alluvial-fan environment. Progress in Physical Geography.Vol.2(1977) No.1, p. 222-270.

[2].Blair, T.C.,Mcpherson, J.G. Alluvial fans and their natural distinction from rivers based on morphology, hydraulic processes, sedimentary processes, and facies assemblages. Journal of Sedimentary Research.Vol.64(1994)No.3,p.581-586.

[3].Stokes, Martin, and A. E. Mather. Controls on modern tributary-junction alluvial fan occurrence and morphology: High Atlas Mountains, Morocco. Geomorphology. Vol. 248(2015),p.344-362.

[4].Yang, L. Field Test of SAGD as Follow-Up Process to CSS in Liaohe Oil Field of China. Journal of Canadian Petroleum Technology.Vol. 46(2007) No.4,p.12-15. 